\title{
Isolation, Purification, and Radiolabeling of a Novel 120-kD Surface Protein on Blastomyces dermatitidis Yeasts to Detect Antibody in Infected Patients
}

Bruce S. Klein and Jeffrey M. Jones

Section of Infectious Disease, Departments of Pediatrics and Medicine, University of Wisconsin Medical School, University of

Wisconsin Hospital and Clinics and the Research Service, William S. Middleton Memorial Veterans Hospital, Madison, Wisconsin 53705

\section{Abstract}

No well-defined Blastomyces-specific antigens are currently available. We used sodium dodecyl sulfate-polyacrylamide gel electrophoresis and immunoblotting to identify immunologically active molecules in the cell wall of $B$. dermatitidis. $A$ major immunoreactive 120-kD protein (WI-1) was present in all five strains studied and comprised $5 \%$ of the protein in the cell wall extract obtained after freezing and thawing yeast cells. WI-1 was recognized by serum from all 10 patients with blastomycosis but by none of those from 5 patients with histoplasmosis. It was purified by electroelution, radiolabeled with ${ }^{125} \mathrm{I}$, and incorporated into a radioimmunoassay (RIA) for serodiagnosis of blastomycosis. Antibody to WI-1 was detected in 58 (85\%) of 68 patients with blastomycosis (geometric mean titer, 1:2,981), in two (3\%) of 73 patients with histoplasmosis, coccidioidomycosis, sporotrichosis, or candidiasis (titers, 1:86 and 1:91) and in none of 44 healthy persons. WI-1 was shown to be a surface molecule abundant on $B$. dermatitidis yeasts that were indirectly stained with serum from a rabbit immunized with WI-1. Approximately 0.93 pg of WI-1 or $4.7 \times 10^{6}$ WI-1 molecules were found on the surface of an individual yeast using an antigen-inhibition RIA; none was found on Histoplasma capsulatum or Candida albicans yeasts. We conclude that WI-1 is a novel, immunologically active surface molecule on the invasive form of $B$. dermatitidis and that WI-1 can be used to reliably detect antibody and study the immunopathogenesis of blastomycosis. (J. Clin. Invest. 1990. 85:152-161.) Blastomyces dermatitidis - blastomycosis - dimorphic fungi • fungal antigens $\bullet$ serodiagnosis

\section{Introduction}

Blastomycosis, one of the principal endemic systemic mycoses, derives from infection with the thermal dimorphic fungus, Blastomyces dermatitidis. Humans and other animals such as dogs are primarily infected by inhaling aerosolized conidia from soil, where the organism dwells as a saprophyte (1). At body temperature, the conidia convert to yeast forms

Presented in part at the 28th Interscience Conference on Antimicrobial Agents and Chemotherapy, Los Angeles, CA, 23-26 October 1988; and the Central Society for Clinical Research, Chicago, IL, 9-11 November 1988.

Address reprint requests to Dr. Klein, Section of Infectious Diseases, University of Wisconsin Hospital and Clinics H4/572, 600 Highland Avenue, Madison, WI 53792.

Received for publication 2 September 1988 and in revised form 28 July 1989.

J. Clin. Invest.

(c) The American Society for Clinical Investigation, Inc. $0021-9738 / 90 / 01 / 0152 / 10 \quad \$ 2.00$

Volume 85, January 1990, 152-161 that can be distinguished from other yeasts by their large size (up to $30 \mu \mathrm{m}$ ), refractile cell wall, and broad-based buds. The acute primary pulmonary infection can be asymptomatic or can produce an influenza or atypical pneumonia syndrome (2). Although acute blastomycotic pneumonia may resolve spontaneously, progressive forms of disease involving the lungs, extrapulmonary organs (usually skin, bones, joints or prostate gland), or both develop in many patients.

Although serologic and skin tests play an important role in the identification and epidemiologic study of other systemic mycoses, especially histoplasmosis and coccidioidomycosis, reliable immune markers of recent and remote $B$. dermatitidis infection are not generally available for noninvasive diagnosis and study of the epidemiologic features of blastomycosis. Two antigens of yeast form $\boldsymbol{B}$. dermatitidis have been described and employed in diagnostic tests: A antigen (serodiagnosis) (3) and Blastomyces alkali- and water-soluble antigen or B-ASWS (in vitro lymphocyte proliferation) (4). Both antigens are impure $(5,6)$, they appear to be a mixture of cell wall components, and tests employing them are not widely available. A further problem with serologic tests using $A$ antigen has been diminished specificity as sensitivity is increased by enzyme immunoassay techniques (7-9). This problem results from A-antigen impurity and the extensive sharing of cell wall components between dimorphic fungi, particularly $B$. dermatitidis and Histoplasma capsulatum.

Previous cell wall composition studies of $\boldsymbol{B}$. dermatitidis yeasts have shown that an $\alpha$-1,3-glucan comprises nearly $95 \%$ of the polymeric glucose and a $\beta$-1,3-glucan comprises the remaining portion; chitin comprises $\sim 37 \%$ of the wall ( 10 , 11). Advances in the characterization of microbial polysaccharases specific for $\alpha$-1,3-glucans, $\beta$-1,3-glucans, and chitin have allowed us to design a rational and comprehensive digestion scheme to investigate the cell wall of $B$. dermatitidis yeasts for immunologically relevant molecules. We describe here the isolation and partial purification and characterization of a $120-\mathrm{kD}$ surface protein that appears to be uniquely expressed on $B$. dermatitidis yeasts and is distinct from components in A-antigen and B-ASWS. We further show that the 120-kD molecule, which we have designated WI-1, can be radiolabeled with ${ }^{125}$ I to reliably detect antibody in infected patients by radioimmunoassay.

\section{Methods}

Fungi. Five American Type Culture Collection (ATCC) strains of $B$. dermatitidis (kindly provided by Dr. Arthur DiSalvo, South Carolina Bureau of Laboratories, Columbia, SC) were studied: 60636, 60637, 26198,32090 , and 26199. The first three strains are soil isolates, 60636 and 60637 having been isolated in association with epidemics of human disease in Wisconsin $(12,13)$, and the latter strains are human isolates. Stock cultures were maintained in the yeast form on $7 \mathrm{H} 10$ agar enriched with oleic acid-albumin complex (Sigma Chemical Co., 
St. Louis, MO) at $37^{\circ} \mathrm{C}$. Yeasts were grown in Erlenmeyer flasks containing brain heart infusion (BHI) ${ }^{1}$ broth (Difco Laboratories, Detroit, MI) at $37^{\circ} \mathrm{C}$ in a gyrator shaker at $120 \mathrm{rpm}$ for $72 \mathrm{~h}$.

Other fungi studied were Candida albicans strain B311-A (ATCC 32354) and a clinical isolate of $H$. capsulatum (kindly provided by James Stoebig, Mycology Section, Wisconsin State Laboratory of Hygiene, Madison). C. albicans was maintained on slants of Sabouraud dextrose agar. Yeasts were grown in Erlenmeyer flasks containing the medium of Lee et al. (14) at $24^{\circ} \mathrm{C}$ in a gyratory shaker at $100 \mathrm{rpm}$ for 24 h. $H$. capsulatum was maintained on slants of BHI agar containing $2 \%$ L-glutamine, $10 \%$ citric acid, and 10\% defribinated sheep blood. Yeasts were grown in Erlenmeyer flasks containing BHI broth at $37^{\circ} \mathrm{C}$ in a gyratory shaker at $120 \mathrm{rpm}$ for $72 \mathrm{~h}$.

All yeasts were harvested by filtration through a sintered glass filter and washed three times with saline. Freshly grown yeasts were used in experiments unless otherwise stated, in which case yeasts that had been stored at $-20^{\circ} \mathrm{C}$ in $20 \mathrm{mM}$ Tris- $\mathrm{HCl}, \mathrm{pH} 6.8$, containing $1 \mathrm{mM} \mathrm{MgCl}$ were used.

B. dermatitidis A antigen (kindly provided by Dr. Leo Kaufman, Centers for Disease Control, Atlanta, GA) and B-ASWS (kindly provided by Dr. Rebecca Cox, San Antonio Chest Hospital, San Antonio, TX) were also used in some experiments.

Extraction of $B$. dermatitidis. Serial extraction of the cell wall was performed as follows. Yeasts that had been stored at $-20^{\circ} \mathrm{C}$ were thawed and centrifuged at $600 \mathrm{~g}$ for $10 \mathrm{~min}$, and the supernatant, which we termed freeze extract, was removed. $10 \mathrm{ml}$ of wet-pelleted organisms were suspended in 10 volumes of fresh $20 \mathrm{mM}$ Tris- $\mathrm{HCl}, \mathrm{pH}$ 6.8 , containing $1 \mathrm{mM} \mathrm{MgCl} 2$ and $5,000 \mathrm{U}$ of mutanolysin (Sigma Chemical Co.), an enzyme product of Streptomyces globisporus (15, 16) with activity for $\alpha$-1,3-glucan linkages. The suspension was incubated overnight in a shaking water bath at $37^{\circ} \mathrm{C}$ and centrifuged at 600 $g$ for $10 \mathrm{~min}$, and the supernatant was removed. Pelleted, mutanolysin-treated yeasts were suspended $(200 \mathrm{mg} / \mathrm{ml})$ in $0.6 \mathrm{M} \mathrm{KCl}, 0.04 \mathrm{M}$ $\mathrm{NaH}_{2} \mathrm{PO}_{4}, \mathrm{pH} 6.0$, containing $7 \mathrm{mM}$ 2-mercaptoethanol and 0.25 $\mathrm{mg} / \mathrm{ml}$ chitinase and $10,000 \mathrm{U} / \mathrm{ml} \beta$-glucuronidase (both from Sigma Chemical Co.). The suspension was incubated in a shaking water bath at $32^{\circ} \mathrm{C}$ for $1 \mathrm{~h}$ and centrifuged at $600 \mathrm{~g}$ for $10 \mathrm{~min}$. The supernatant was removed and heated in a shaking water bath at $56^{\circ} \mathrm{C}$ for $1 \mathrm{~h}$.

To prepare a cytoplasmic extract, $15 \mathrm{ml}$ of freshly grown, washed yeast cells were suspended in $35 \mathrm{ml}$ of Tris buffer and the suspension was passed through a French pressure cell at $1,100 \mathrm{~kg} / \mathrm{cm}^{2}$. Cellular debris was removed from the effluent by centrifuging at $12,000 \mathrm{~g}$ for $30 \mathrm{~min}$.

Supernatants removed after cell wall and cytoplasmic extractions were dialyzed for $48 \mathrm{~h}$ against deionized-distilled water in nitrogenpurged dialysis tubing with a 3,500-mol wt exclusion. Dialysates were lyophilized to obtain dry extracts. The protein content of extracts was estimated using the BCA protein assay reagent (Pierce Chemical Co., Rockford, IL) with BSA (nitrogen, $15.4 \%$ ) as a standard. Lactic dehydrogenase (LDH) activity in extracts, which was used as a marker of the cytoplasmic origin of material, was determined using the method of Wroblewski and LaDue (17). $1 \mathrm{U}$ of LDH activity was defined as a change of $0.001 / \mathrm{min}$ in the $\mathrm{OD}_{340}$ of the assay solution at $25^{\circ} \mathrm{C}$ measured using a $1-\mathrm{cm}$ light path.

Electron micrographs (EMs). An aliquot of yeast suspension was fixed overnight at $4^{\circ} \mathrm{C}$ in $2.5 \%$ glutaraldehyde/sodium phosphate buffer $(0.1 \mathrm{~mol} /$ liter, $\mathrm{pH} 7.4)$, washed in phosphate buffer solution, postfixed in $1 \%$ osmium tetroxide for $2 \mathrm{~h}$, and dehydrated in graded concentrations of ethanol. For transmission EMs, the treated yeast suspension was embedded in Epon. Thin sections were stained with uranyl acetate and lead citrate, mounted on copper grids (200 mesh), and examined in an electron microscope (H-300; Hitachi, Tokyo,

1. Abbreviations used in this paper: BHI, brain heart infusion; EM, electron micrograph; GMT, geometric mean titer; IFA, indirect fluorescent antibody; LDH, lactic dehydrogenase; TBS, Tris-buffered saline.
Japan). For scanning EMs, the treated yeast suspension was criticalpoint dried, coated with gold, and examined in a scanning electron microscope (JSM-U3; JEOL Corp., Peabody, MA).

Sodium dodecyl sulfate-polyacrylamide gel electrophoresis (SDS$P A G E$ ). Samples were prepared for SDS-PAGE analysis by dissolving an extract at a concentration of $40 \mathrm{mg}$ (dry wt)/ml in sample buffer containing $0.125 \mathrm{M}$ Tris-HCl, $4 \%$ (wt/vol) SDS, $2 \%$ (wt/vol) glycerol, and $10 \%$ (vol/vol) 2-mercaptoethanol (pH 6.8). After boiling for $2 \mathrm{~min}$, samples were electrophoresed on $10 \%$ SDS-PAGE slab gels as described by Laemmli (18). Gels were stained for protein with Coomassie brilliant blue or silver nitrate (19) and for carbohydrate by the periodic acid-Schiff (PAS) method (20).

Western blots. Upon completion of SDS-PAGE, Western blots of gels were prepared as described by Towbin et al. (21). Nitrocellulose paper was placed on the gel in a cassette in a Transphor electrophoresis chamber (Hoefer Scientific Instruments, San Francisco, CA) filled with $20 \mathrm{mM}$ Tris base containing $150 \mathrm{mM}$ glycine and $20 \%$ (vol/vol) methanol. Gel components were transferred to the nitrocellulose paper by passing a current transversely across the cassette for $18 \mathrm{~h}$ at $70 \mathrm{~V}$. The nitrocellulose was placed in a solution of $3 \%$ BSA in Tris-buffered saline (TBS) (BSA-TBS; $50 \mathrm{mM}$ Tris- $\mathrm{HCl}, 200 \mathrm{mM} \mathrm{NaCl}$ [pH 7.4]) at $40^{\circ} \mathrm{C}$ to saturate unoccupied sites on the paper with albumin. The paper was cut vertically into strips and a strip was incubated for $2 \mathrm{~h}$ at room temperature with the desired serum diluted 1:10 in TBS. Strips were washed in six changes of saline ( $5 \mathrm{~min}$ each) and exposed to the appropriate conjugate, either peroxidase-conjugated sheep anti-rabbit IgG or peroxidase-conjugated rabbit anti-human IgG (Cooper Biomedical, Inc., West Chester, PA). Conjugates were diluted 1:2,000 in saline containing 3\% (wt/vol) BSA and $10 \%(\mathrm{vol} / \mathrm{vol})$ fetal calf serum. Nitrocellulose strips were again washed in saline and developed for 30 min with a substrate solution $(0.05 \%$ [wt/vol] 4-chloro-1-naphthol [Sigma Chemical Co.], 0.015\% [vol/vol] $\mathrm{H}_{2} \mathrm{O}_{2}$ in TBS).

The above technique was modified slightly for miniblots. After unoccupied sites on the nitrocellulose were saturated with albumin, the uncut paper was placed into a 48-lane miniblotting apparatus (Immunetics, Inc., Boston, MA). Reagents and steps were otherwise the same as above.

Partial purification of protein antigen. An electrophoretic concentrator (Isco, Inc., Lincoln, NE) was used to elute and concentrate WI-1 from crude cell-wall extracts. After an extract was separated on a $10 \%$ SDS-PAGE gel, the location of WI-1 was estimated from knowledge of its molecular weight and the location in the gel of prestained molecular weight markers. An 0.5-cm horizontal strip was cut from the unstained gel corresponding to the $118-\mathrm{kD}$ molecular weight marker, $\beta$-galactosidase. The gel strip was cut into pieces and placed in a transparent polycarbonate sample cup having a small and a large well that contained a 1:10 dilution of $25 \mathrm{mM}$ Tris-base, $\mathrm{pH} 8.3$, and $192 \mathrm{mM}$ glycine; the cup in turn was bathed in a buffer tank containing the undiluted buffer. $3 \mathrm{~W}$ were applied across the buffer tank for $4 \mathrm{~h}$ to elute WI-1 from the gel and concentrate it in $250 \mu \mathrm{l}$ of buffer in the small well, whose base was covered with a membrane having a 3,500mol wt exclusion. This eluate was further concentrated by centrifugation at $5,000 \mathrm{~g}$ for $30 \mathrm{~min}$ in a Centricon tube (Amicon Corp., Danvers, MA). The purity of the eluate was assessed by SDS-PAGE, and the protein content by using the Pierce reagent.

$R I A$. Target antigen in the RIA was labeled with ${ }^{125} \mathrm{I}$ using $N$ chlorobenzenesulfonamide as an oxidizing agent (22). By adjusting labeling conditions, we could vary the specific radioactivity of ${ }^{125} \mathrm{I}-\mathrm{WI}$ 1 between 2,000 and $10,000 \mathrm{cpm} / \mathrm{ng}$. When labeled to a specific radioactivity of $2,000 \mathrm{cpm} / \mathrm{ng}$, the capacity of ${ }^{125} \mathrm{I}-\mathrm{WI}-1$ to bind specific antibody was stable for at least $1 \mathrm{mo}$. Counting efficiency of the gamma counter was $60 \%$.

We used 1\% BSA in $0.04 \mathrm{M} \mathrm{NaH}_{2} \mathrm{PO}_{4}, 0.15 \mathrm{M} \mathrm{NaCl}, \mathrm{pH} 7.5$ (PBS) as the carrier solution in the RIA. All sera being tested were diluted serially in BSA-PBS in flat-bottom, 96-well microtiter plates (Costar, Cambridge, MA). Dilutions of 1:40 and greater were tested. Each experimental or control serum sample was analyzed in duplicate. A test sample consisted of $0.1 \mathrm{ml}$ of diluted serum and $0.1 \mathrm{ml}$ of BSA-PBS 
containing $5 \mathrm{ng}$ of ${ }^{125} \mathrm{I}-$ WI-1. Coprecipitation controls for antibody measurements contained $0.1 \mathrm{ml}$ of BSA-PBS in place of diluted test serum. After incubating for $1 \mathrm{~h}$ at $37^{\circ} \mathrm{C}$ and overnight at $4^{\circ} \mathrm{C}, 1 \mathrm{mg}$ of staphylococcal protein A (Sigma) in $0.2 \mathrm{ml}$ of PBS was added to each sample. Precipitates were centrifuged at $2,000 \mathrm{~g}$ for $10 \mathrm{~min}$ at room temperature and $0.2 \mathrm{ml}$ of each supernatant was counted in a gamma counter.

Coprecipitation was corrected for in all RIAs by the method of Minden and Farr (23). Coprecipitation never exceeded $10 \%$ of labeled antigen added and was usually under $5 \%$. The dilution of each test serum that specifically bound $20 \%$ of the labeled antigen dose was calculated by linear regression analysis (22), using the data points of the three dilutions that gave binding values closest to $20 \%$. A standard lot of rabbit antiserum derived by immunizing the animal with unlabeled WI-1 was assayed with each run of experimental sera titered for antibody to the labeled antigen. This insured that there was no significant run-to-run variation in the sensitivity of the assay. Based on six determinations of the specific antibody level in the standard rabbit antiserum, the standard deviation of the mean of these values, $\pm 2 \%$, was taken as a measure of the precision of the RIA to measure the antibody.

The RIA was used to quantitate the amount of WI- 1 on the surface of $B$. dermatitidis (strain 60636), $H$. capsulatum and $C$. albicans yeasts. The specific inhibition of binding of ${ }^{125} \mathrm{I}-\mathrm{WI}-1$ to diluted rabbit antiserum was measured for unlabeled WI-1 and these yeasts. Each assay tube contained $0.1 \mathrm{ml}$ of rabbit antiserum diluted in a carrier solution $(1: 80, \mathrm{vol} / \mathrm{vol}, 1 \% \mathrm{BSA}-\mathrm{PBS})$ so as to bind $\sim 60 \%$ of $5 \mathrm{ng}$ of ${ }^{125} \mathrm{I}-\mathrm{WI}-1$. Inhibitor (either unlabeled antigen or yeasts in $0.1 \mathrm{ml}$ of BSA-PBS) was added to each tube and the tubes were incubated at $37^{\circ} \mathrm{C}$ for $1 \mathrm{~h}$ and $4^{\circ} \mathrm{C}$ for $4 \mathrm{~h}$. Then, ${ }^{125} \mathrm{I}-\mathrm{WI}-1(5 \mathrm{ng}$ in $0.1 \mathrm{ml}$ of BSA-PBS) was added to each tube and the tubes were incubated at $37^{\circ} \mathrm{C}$ for $1 \mathrm{~h}$ and at $4^{\circ} \mathrm{C}$ overnight. The amount of ${ }^{125} \mathrm{I}$-WI-1 specifcally bound to antibody was determined for each tube. To generate a standard inhibition curve, solutions with known quantities of unlabeled antigen $(0.25-500 \mathrm{ng}$ in $0.1 \mathrm{ml})$ were used as inhibitors.

Experimental and control serum samples. Human sera tested were from patients with endemic or epidemic-related cases of blastomycosis, histoplasmosis, coccidioidomycosis, sporotrichosis, or candidiasis and from healthy persons (Table I). Clinical information was available in all 68 patients with blastomycosis and in $63(86 \%)$ of 73 control subjects with other fungal diseases. 34 blastomycosis patients had acute pulmonary infection, 22 had chronic pulmonary disease, 9 had chronic pulmonary and extrapulmonary disease, and 3 had isolated cutaneous disease. 10 histoplasmosis patients had acute pulmonary infection, 10 had chronic pulmonary disease, and 4 had disseminated disease; no clinical information was available in the remaining 10 histoplasmosis patients. 7 coccidioidomycosis patients had acute pulmonary infection, 5 had chronic pulmonary disease, and 10 had disseminated disease. 10 sporotrichosis patients had isolated cutaneous disease and 1 had cavitary pulmonary disease. The six candidiasis patients had invasive infection in association with hematologic malignancy. Most sera were stored at $-70^{\circ} \mathrm{C}$ for up to $4 \mathrm{yr}$, however, those from Arkansas patients with blastomycosis had been stored at $-20^{\circ} \mathrm{C}$. Many sera from Wisconsin patients with blastomycosis had been thawed and refrozen at least three times.

Rabbit antiserum was produced in a New Zealand white rabbit

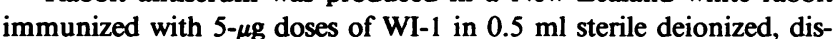
tilled water. Subcutaneous injections were given weekly for $4 \mathrm{wk}$ in 0.5 $\mathrm{ml}$ complete Freund adjuvant, and then biweekly in $0.5 \mathrm{ml}$ incomplete Freund adjuvant. Other rabbits were immunized with weekly subcutaneous or intravenous injections of $10^{8}$ formalin-inactivated $B$. dermatitidis yeasts in $0.5 \mathrm{ml}$ complete Freund adjuvant.

Indirect fluorescent antibody (IFA) staining and immunogold staining. For IFA staining, each well of a Teflon-coated, 12-well microslide (Carlson Scientific, Peotone, IL) was precoated with polylysine $\left(1 \mathrm{mg} / \mathrm{ml}\right.$ of sterile deionized water) (Sigma), and $10^{4} \mathrm{~B}$. dermatitidis or $H$. capsulatum yeasts in $10 \mu \mathrm{l}$ of $0.01 \mathrm{M}$ PBS, $\mathrm{pH} 7.2$, were added to the well. The slide was air dried and rinsed briefly in PBS. Immune or preimmune rabbit serum was serially diluted in PBS and $10 \mu$ l of each dilution or of PBS as a control was added to each well. Serum dilutions of $1: 4$ and greater were tested. The slides were incubated at $37^{\circ} \mathrm{C}$ for 30 $\min$ in a humidified container. They were rinsed in PBS with agitation for $15 \mathrm{~min}$ and air dried. A $10-\mu \mathrm{l}$ aliquot of fluorescein-conjugated goat anti-rabbit IgG (Cappel Laboratories, Cochranville, PA) diluted 1:160 in PBS containing $0.05 \%$ (wt/vol) Tween 20 and $0.05 \%$ (wt/vol) Evans blue was added to each well and slides were again incubated at $37^{\circ} \mathrm{C}$ for $30 \mathrm{~min}$ in a humidified container. Slides were again rinsed in PBS and air dried. Carbonate-glycerol, pH 9, was added to each well and a coverslip was applied. Slides were examined under oil immersion at $\times 100$ using a microscope equipped to detect reflected fluorescence (BH-2; Olympus Optical Co., Tokyo, Japan).

For immunogold staining, $10^{7}$ fresh $B$. dermatitidis yeast cells were suspended in $1 \mathrm{ml}$ of BSA-PBS at room temperature for $15 \mathrm{~min}$ using constant rotation. Samples were centrifuged at $600 \mathrm{~g}$ for $5 \mathrm{~min}$ and the supernatant was removed. Preimmune, immune, or WI-1 antigen- and yeast-adsorbed immune serum was serially diluted in BSA-PBS and 1 $\mathrm{ml}$ of each dilution or of BSA-PBS as a control was added to the sample of yeasts. Serum dilutions of 1:100 and greater were tested. Samples were incubated at room temperature for $2 \mathrm{~h}$ using constant rotation. Yeasts were washed in PBS and centrifuged three times. Protein A-gold containing 14-nm particles was prepared using the method of Lucocq and Roth (25). It was diluted 1:15 in BSA-PBS and $1 \mathrm{ml}$ added to each sample of yeasts. Samples were incubated at room temperature for $1 \mathrm{~h}$ using constant rotation. Yeasts were again washed in PBS three times and prepared as described for examination in a Hitachi H-300 electron microscope (Hitachi).

Statistical analysis. Mean values for titers of specific anti-Blastomyces antibody were expressed as reciprocal geometric mean titers (GMTs) \pm 1 SEM. Mean values for other parameters were given as arithmetic means \pm 1 SEM. The significance of differences between groups was determined with the chi-square test, or Fisher's exact test for categorical variables. The sensitivities of different assays for detection of anti-Blastomyces antibody were compared using a test of relative difference (26). Geometric mean titers were compared using the Wilcoxon test. $P$-values reported are based on two-tailed levels of significance.

\section{Results}

Cell wall extracts. 25-g yeast pellets of the five ATCC strains of B. dermatitidis yielded a mean of $47 \pm 10 \mathrm{mg}$ of extract (dry weight) after freezing (range, 20 to $70 \mathrm{mg}$ ), a mean of $92 \pm 9 \mathrm{mg}$ after treatment with mutanolysin (range, 71 to $115 \mathrm{mg}$ ), and $695 \mathrm{mg}$ after treatment with chitinase and $\beta$-glucuronidase (only one strain, 60636, was extracted with the latter two enzymes). Freeze extracts had a mean protein content of $34 \pm 8 \%$ (range, 13 to 63\%); extracts from mutanolysin treatment had a mean protein content of $46 \pm 10 \%$ (range, 21 to $73 \%$ ); and the one from chitinase and $\beta$-glucuronidase treatment had a protein content of $68 \%$.

SDS-PAGE analysis showed a wide spectrum of proteins removed from the cell wall of $B$. dermatitidis by these extraction procedures (Fig. 1). Most components in the extracts stained with Coomassie blue rather than with PAS. For comparison with these extracts, we studied B-ASWS and A-antigen by SDS-PAGE. B-ASWS appeared polydispersed. A-antigen showed a major 64-kD component in addition to a large number of other bands.

Immunoblotting. Western blots were made from $10 \%$ SDS-PAGE gels loaded with $25 \mathrm{mg}$ of a given cell wall extract either pooled between several strains or from a representative strain of $B$. dermatitidis. Sera from patients with blastomycosis or histoplasmosis or from healthy persons were used to 
Table I. Characteristics of 267 Serum Specimens from 185 Patients and Controls Tested for Anti-Blastomyces Antibody using a Radioimmunoassay Developed in the Present Study

\begin{tabular}{|c|c|c|c|}
\hline Type of patient or control & Institution* & $\begin{array}{l}\text { No. of patients } \\
\text { or controls } \\
\text { (No. of sera) }\end{array}$ & Previous serologic test results \\
\hline \multicolumn{4}{|l|}{ Blastomycosis } \\
\hline $\begin{array}{l}\text { Eagle River epidemic cases of } \\
\text { blastomycosis }\end{array}$ & University of Wisconsin & $20(20)$ & $\begin{array}{l}\text { Anti-A antigen titers of } 1: 8 \text { to } 1: 512 \text { (median, } \\
1: 128 \text { ) by enzyme immunoassay (reference } 8 \text { ) }\end{array}$ \\
\hline $\begin{array}{l}\text { Crystal River and Tomorrow } \\
\text { River epidemic cases of } \\
\text { blastomycosis }\end{array}$ & University of Wisconsin & $13(47)$ & $\begin{array}{l}\text { Anti-A antigen titers of } 1: 8 \text { to } 1: 32 \text { (median, } 1: 8 \text { ) } \\
\text { by enzyme immunoassay (reference } 13 \text { ) }\end{array}$ \\
\hline \multirow[t]{4}{*}{$\begin{array}{l}\text { Endemic cases of } \\
\text { blastomycosis }\end{array}$} & $\begin{array}{l}\text { University of Arkansas for Medical } \\
\text { Sciences }\end{array}$ & $23(59)$ & $\mathrm{NA}^{\ddagger}$ \\
\hline & Wisconsin State Laboratory of Hygiene & $8(12)$ & NA \\
\hline & University of Wisconsin & $4(12)$ & NA \\
\hline & & $68(150)$ & \\
\hline \multicolumn{4}{|l|}{ Other mycoses } \\
\hline \multirow[t]{4}{*}{$\begin{array}{l}\text { Epidemic and endemic cases } \\
\text { of histoplasmosis }\end{array}$} & $\begin{array}{l}\text { Veterans Administration Hospital, } \\
\text { Lexington, } \mathrm{KY}\end{array}$ & $14(14)$ & $\begin{array}{l}\text { Yeast-phase complement fixation titers of } 1: 64 \\
\text { to } 1: 256 \text { (median, } 1: 128 \text { ) }\end{array}$ \\
\hline & Indiana University School of Medicine & $6(6)$ & $\begin{array}{l}\text { Yeast- or mycelial-phase complement fixation } \\
\text { titers of } 1: 8 \text { to } 1: 64 \text { (median, } 1: 64 \text { ) }\end{array}$ \\
\hline & Wisconsin State Laboratory of Hygiene & $12(12)$ & $\begin{array}{l}\text { Yeast-phase complement fixation titers of } 1: 8 \text { to } \\
1: 256 \text { (median, } 1: 64 \text { ) }\end{array}$ \\
\hline & $\begin{array}{l}\text { University of Arkansas for Medical } \\
\text { Sciences }\end{array}$ & $2(2)$ & NA \\
\hline \multirow[t]{2}{*}{$\begin{array}{l}\text { Endemic cases of } \\
\text { coccidioidomycosis }\end{array}$} & $\begin{array}{l}\text { The University of Arizona Health } \\
\text { Sciences Center }\end{array}$ & $16(16)$ & $\begin{array}{l}\text { Complement fixation titers of } 1: 4 \text { to } 1: 64 \\
\text { (median, 1:32) }\end{array}$ \\
\hline & $\begin{array}{l}\text { Veterans Administration Hospital, } \\
\text { Lexington, } \mathrm{KY}\end{array}$ & $6(6)$ & $\begin{array}{l}\text { Complement fixation titers of } 1: 16 \text { to } 1: 64 \\
\text { (median, 1:64) }\end{array}$ \\
\hline \multirow[t]{2}{*}{$\begin{array}{l}\text { Epidemic and endemic cases } \\
\text { of sporotrichosis }\end{array}$} & New York State Department of Health & $10(10)$ & $\begin{array}{l}\text { Slide latex agglutination titers of } 1: 4 \text { to } 1: 32 \\
\text { (median, } 1: 8 \text { ) }\end{array}$ \\
\hline & $\begin{array}{l}\text { University of Arkansas for Medical } \\
\text { Sciences }\end{array}$ & $1(1)$ & NA \\
\hline \multirow[t]{2}{*}{ Candidiasis } & University of Wisconsin & $6(6)$ & Multiple of normal ELISA absorbance values of \\
\hline & & $73(73)$ & 2.21 to 6.10 (median, 2.72) (reference 24$)$ \\
\hline \multicolumn{4}{|l|}{ Healthy subjects } \\
\hline Medical housestaff and faculty & University of Wisconsin & $44(44)$ & NA \\
\hline
\end{tabular}

* Persons providing sera from these institutions were Dr. Robert Bradsher (University of Arkansas for Medical Sciences), Ruth Dodge (Wisconsin State Laboratory of Hygiene), Dr. John Galgiani (University of Arizona Health Sciences Center), Dr. James Johnson (Veterans Administration Hospital), Dr. Ira Salkin (New York State Department of Health), and Dr. L. Joseph Wheat (Indiana University School of Medicine).

‡Not available.

develop the blots to identify immunoreactive molecules in the cell wall recognized only by the first group. A $120-\mathrm{kD}$ protein in the freeze extract was recognized by all 10 patients with blastomycosis, but by none of the five with histoplasmosis and none of the four healthy persons (Fig. 2). Western blots using 33 sera from an additional 25 patients with blastomycosis and both postimmunization sera from two immunized rabbits consistently showed staining of the $120-\mathrm{kD}$ molecule, whereas preimmunization sera from the rabbits did not (data not shown).

Partial purification and characterization of the $120-\mathrm{kD}$ molecule. Strain 60636 was used in these experiments. $40 \mathrm{mg}$ of the crude extract derived by freezing and thawing the organism was loaded onto a $10 \%$ gel along with a prestained molecular weight marker. The buffer front was run past the anode for approximately $90 \mathrm{~min}$ to separate the $120-\mathrm{kD}$ molecule from other extract components that resolved nearby. A $0.5-\mathrm{cm}$ strip cut from the gel at the estimated region of this molecule thereby gave a purer protein fraction than would otherwise be possible. When analyzed by SDS-PAGE, the protein eluted from such gel strips generally yielded a single band when stained with Coomassie blue (Fig. 3). The band could not be visualized with PAS stain. Silver staining of gels loaded with some eluates demonstrated a nonhomogeneous mixture of molecules, including a major $120-\mathrm{kD}$ component and minor components that resolved at slightly lower molecular weights. Eluates obtained from multiple electroelutions were pooled and concentrated. The final protein concentration of this material was $4 \mathrm{mg} / \mathrm{ml}$.

Densitometry readings of the crude freeze extract showed 

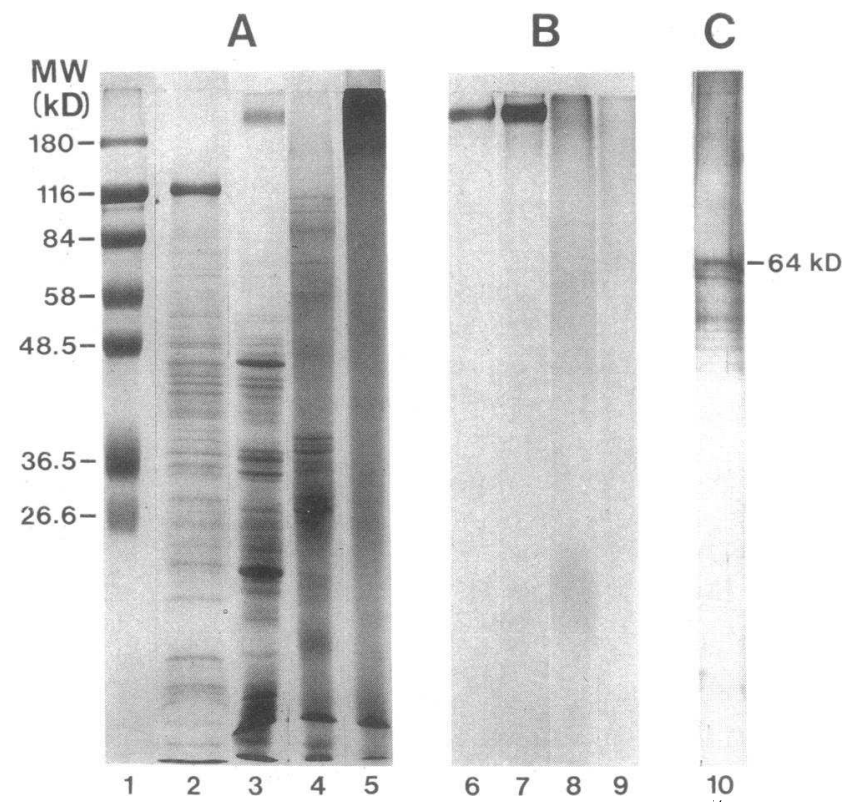

Figure 1. Cell-wall extracts of yeast-form $B$. dermatitidis and standard antigens of the yeast (B-ASWS and A-antigen) analyzed by SDS-PAGE. $(A)$ A $10 \%$ SDS-PAGE gel stained with Coomassie brilliant blue. Samples in each lane contain 200-300 $\mu \mathrm{g}$ of protein. Molecular weight standards are shown in lane 1. Extracts of ATCC strain 60636 were derived by freezing organisms at $-20^{\circ} \mathrm{C}$ (lane 2), treating with mutanolysin after organisms had been frozen (lane 3 ), and treating with chitinase and $\beta$-glucuronidase combined after the organisms had been treated with mutanolysin (lane 4). B-ASWS (lane 5) was isolated from the yeast cell wall as previously described (4). (B) A 10\% SDS-PAGE gel stained by the periodic acid-Schiff method. The samples studied in lanes 6 to 9 , and their order of appearance and protein content, are the same as in A. (C) A 10\% SDSPAGE gel of purified A-antigen stained with Coomassie brilliant blue and then silver nitrate. The antigen yielded a complement fixation titer of 1:64 and enzyme immunoassay titer of 1:200 using a standard reference serum from a known seropositive person. $20 \mu l$ of this sample was loaded into lane 10 . Note major band at $64 \mathrm{kD}$ and large number of other components in material.

that the molecule of interest resolved at $120 \pm 5 \mathrm{kD}$ in strain 60636, however, slight variability in expression and size was noted among the five ATCC strains studied (Fig. 4). Integration of the densitometry readings showed that the $120-\mathrm{kD}$ molecule comprised $5 \%$ of the total protein present in the crude freeze extract of strain 60636.

Boiling the crude extract at $100^{\circ} \mathrm{C}$ for $15 \mathrm{~min}$ or storing it at $-20^{\circ} \mathrm{C}$ either as a lyophilized powder or dissolved in treatment buffer did not appreciably alter the integrity of the 120kD molecule as judged by SDS-PAGE. However, when several large batches of freeze extract were concentrated at $40^{\circ} \mathrm{C}$ using a YM 100 filter (Amicon Corp.) before dialysis and lyophilization, the intensity of the band corresponding to WI-1 on SDS-PAGE gels loaded with the resultant material was diminished and the apparent molecular weight of WI-1 decreased to as low as $115 \mathrm{kD}$.

EM and IFA and immunogold staining helped to identify the cell wall location of the $120-\mathrm{kD}$ molecule. Freezing roughened the cell wall surface morphologically but did not appear to compromise its integrity (Fig. 5), suggesting that the $120-\mathrm{kD}$ molecule and other components in this crude extract represent

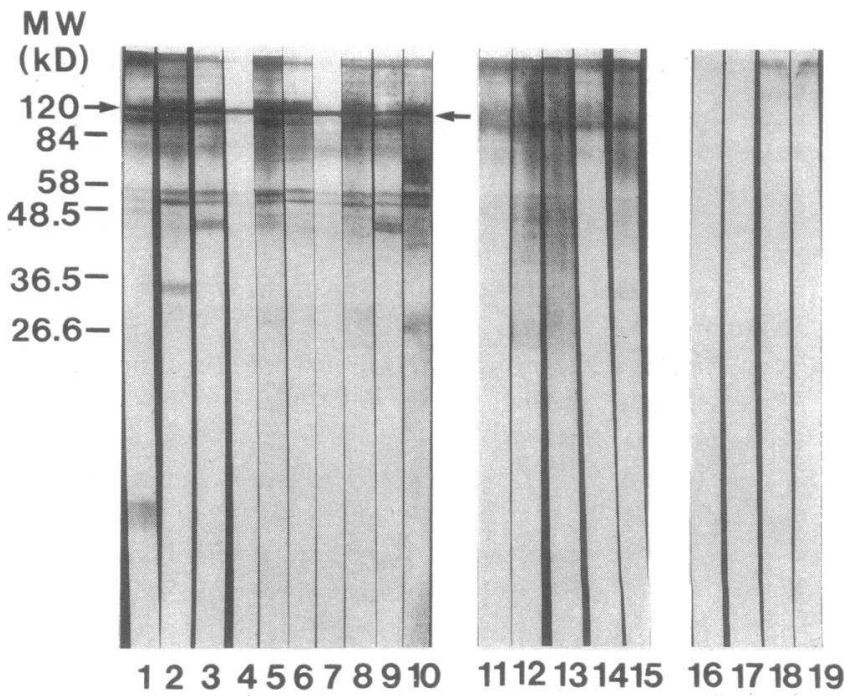

Figure 2. Spectrum of cell wall components in freeze extract of $B$. dermatitidis yeasts recognized by human sera. Western blots of $10 \%$ SDS-PAGE gels loaded with extract derived by freezing yeasts of ATCC strain 60636 at $-20^{\circ} \mathrm{C}$. Blots in lanes $1-10$ were stained with sera from patients with blastomycosis (A-antigen titers by enzyme immunoassay of $1: 32$ to $1: 128$; median titer, 1:48). Blots in lanes 11-15 were stained with sera from patients with histoplasmosis (yeast-phase complement fixation titers of 1:64 to 1:256; median titer, 1:128). Blots in lanes 16-19 were stained with sera from healthy persons with no history of systemic mycosis. Arrows indicate staining of $120 \mathrm{kD}$ protein by sera from patients with blastomycosis.

superficial cell wall determinants. Consistent with this hypothesis, serum from a rabbit immunized with the $120-\mathrm{kD}$ molecule stained the surface of $B$. dermatitidis yeasts in the IFA and immunogold tests (Figs. $5 C$ and 6), whereas preimmune serum from this animal and the PBS control did not. Staining by immune serum was abrogated by prior adsorption with WI-1 and $B$. dermatitidis yeasts, and was judged insignificant when using $H$. capsulatum yeasts as the target in the IFA test (data not shown).

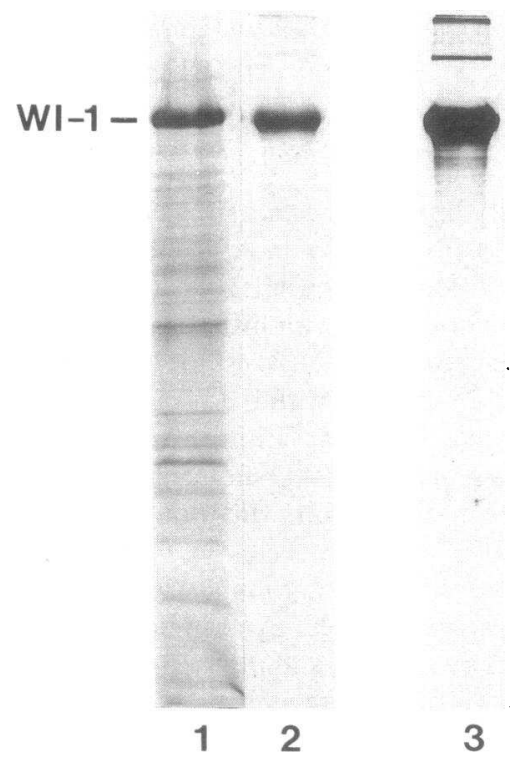

Figure 3. Partially purified WI-1, a novel 120$\mathrm{kD}$ surface protein on $B$. dermatitidis yeasts. A $10 \%$ SDS-PAGE gel of the crude extract obtained after freezing $B$. dermatitidis yeast strain 60636 at $-20^{\circ} \mathrm{C}$ (lane 1) and of the electrophoretically eluted, concentrated and pooled samples of WI-1 taken from the extract (lanes 2 and 3). The gel has been stained with Coomassie brilliant blue (lanes 1 and 2) and then silver nitrate (lane 3 ) to demonstrate the purity of WI-1. 


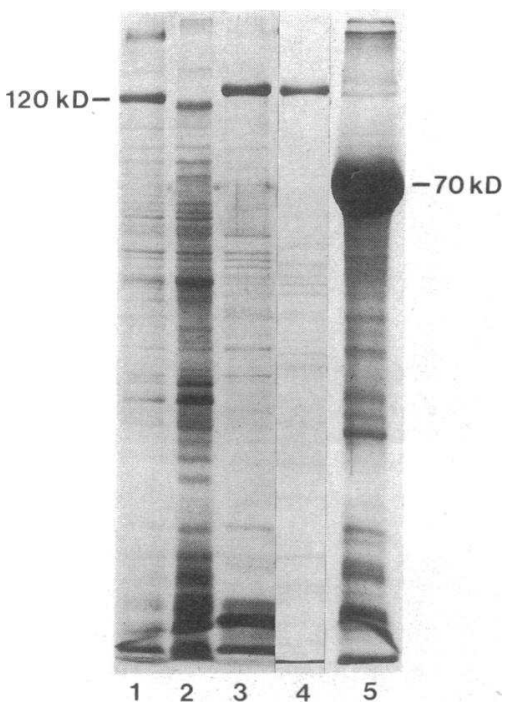

To exclude gross contamination of freeze extract by cytoplasmic material, we determined LDH activity in two freeze extracts and two cytoplasmic extracts. Solutions of extracts were adjusted to contain $5 \mathrm{mg}$ protein/ $\mathrm{ml}$. Under these conditions, no LDH activity was detected in freeze extracts; how- ever, cytoplasmic extracts contained a mean of $12.8 \mathrm{LDH}$ $\mathrm{U} / \mathrm{mg}$ protein.

Detection of antibody to WI-1 by RIA in infected patients and in control subjects. A total of 267 sera from 185 patients and control subjects were tested by RIA for antibody to WI-1. Single sera were available for 35 of the 68 patients with blastomycosis; a median of three sera per patient (range, 1 to 9) were available for the remaining 33 patients. Single sera were available for patients with other mycoses and healthy persons. An antibody titer of $1: 40$ or greater was detected in $58(85 \%)$ of the 68 patients with blastomycosis, but in only $2(3 \%)$ of the 73 patients with other mycoses $\left(P<1 \times 10^{-8}\right)$ and in none of the 44 healthy persons $\left(P<1 \times 10^{-8}\right)$ (Fig. 7). The reciprocal GMT of antibody in patients with blastomycosis was $2,981 \pm 1$, whereas the titers in the two seropositive patients with histoplasmosis were 86 and 91, respectively. One of these patients had acute pulmonary infection and no clinical information was available in the other patient. From the results presented, the sensitivity, specificity, and positive and negative predictive values of detection of antibody to WI- 1 by RIA are $85 \%, 98 \%$, $97 \%$, and $92 \%$, respectively. If the positive cutoff value is increased from a titer of 1:40 to a titer of 1:100 (a value just above both seropositive controls with histoplasmosis), all cases remain seropositive and the respective measures of the test would be $85 \%, 100 \%, 100 \%$, and $92 \%$.

The sensitivity of the RIA for detection of antibody to WI-1 was compared to that of an enzyme immunoassay for detection of antibody to A antigen; 76 sera from 38 of the
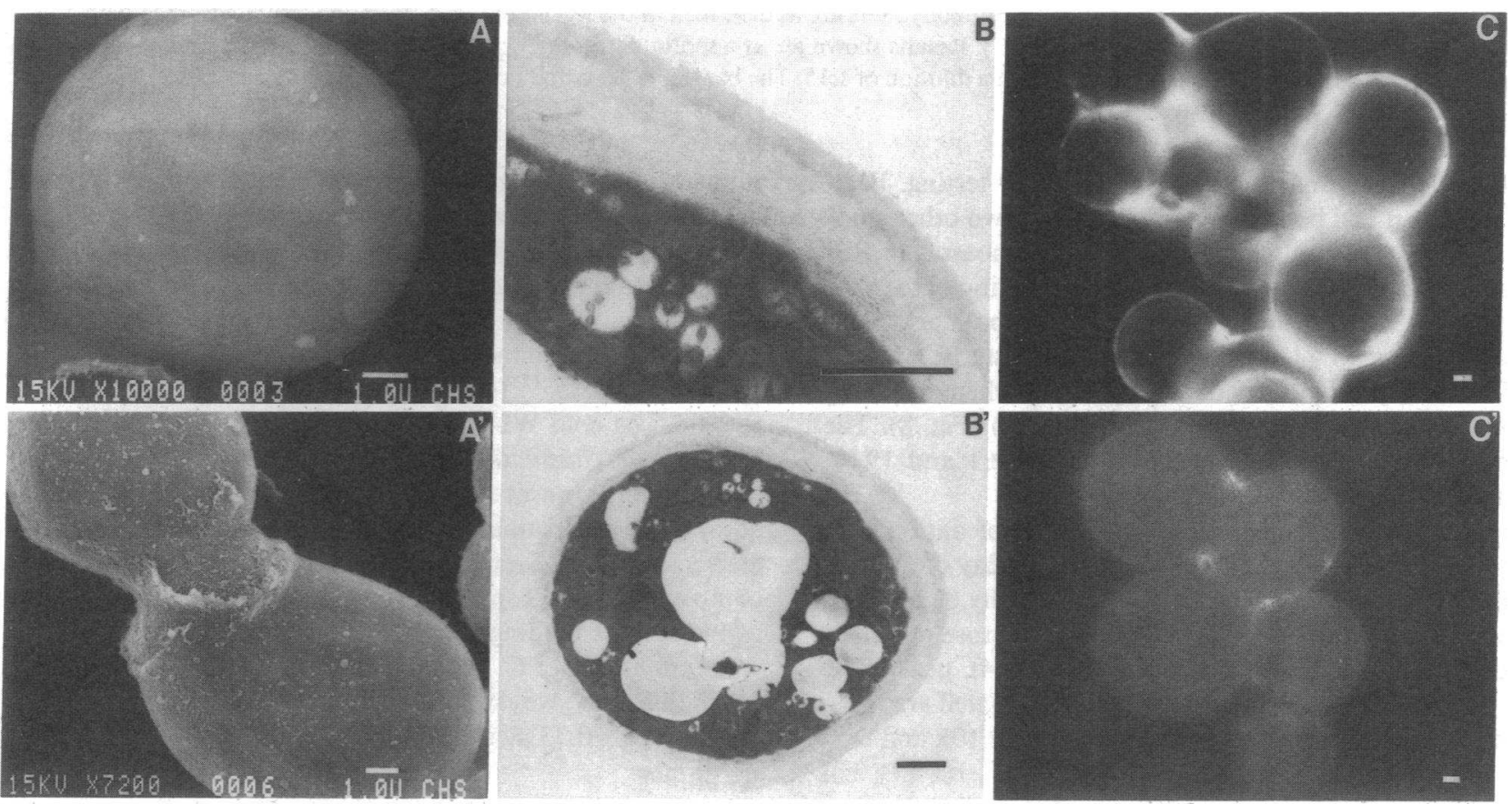

Figure 5. Cell wall location of WI-1 in B. dermatitidis yeasts. $(A$ and $B$ ) EMs demonstrating effects of treatments on outer cell wall of organism. The bar in the lower right corner of each photo denotes a size of $1 \mu \mathrm{m}$. $(A)$ Scanning EM of organisms. Note smooth surface of yeasts that have received no treatment (top). Some roughening of cell surface is noted and material can be seen peeling from cell surface of yeasts after freezing at $-20^{\circ} \mathrm{C}($ bottom). (B) Transmission EM of organisms after freezing. The electron dense outer layer of the cell wall appears roughened (top) but the cytoplasm of the cell remains intact (bottom). $(C)$ Indirect fluorescent antibody staining of $B$. dermatitidis yeasts. Serum from a rabbit immunized with WI-1 was used to stain the yeasts (top) and preimmune serum served as a control (bottom). Antibody to WI-1 was detected at a titer of 1:5, 120 in immune serum and was undetectable in preimmune serum using RIA. Sera were tested at dilutions of 1:4 to 1:64. Immune serum stained the yeast intensely at all dilutions, whereas preimmune serum showed little or no staining of the yeasts. Results shown are at a dilution of 1:16. 


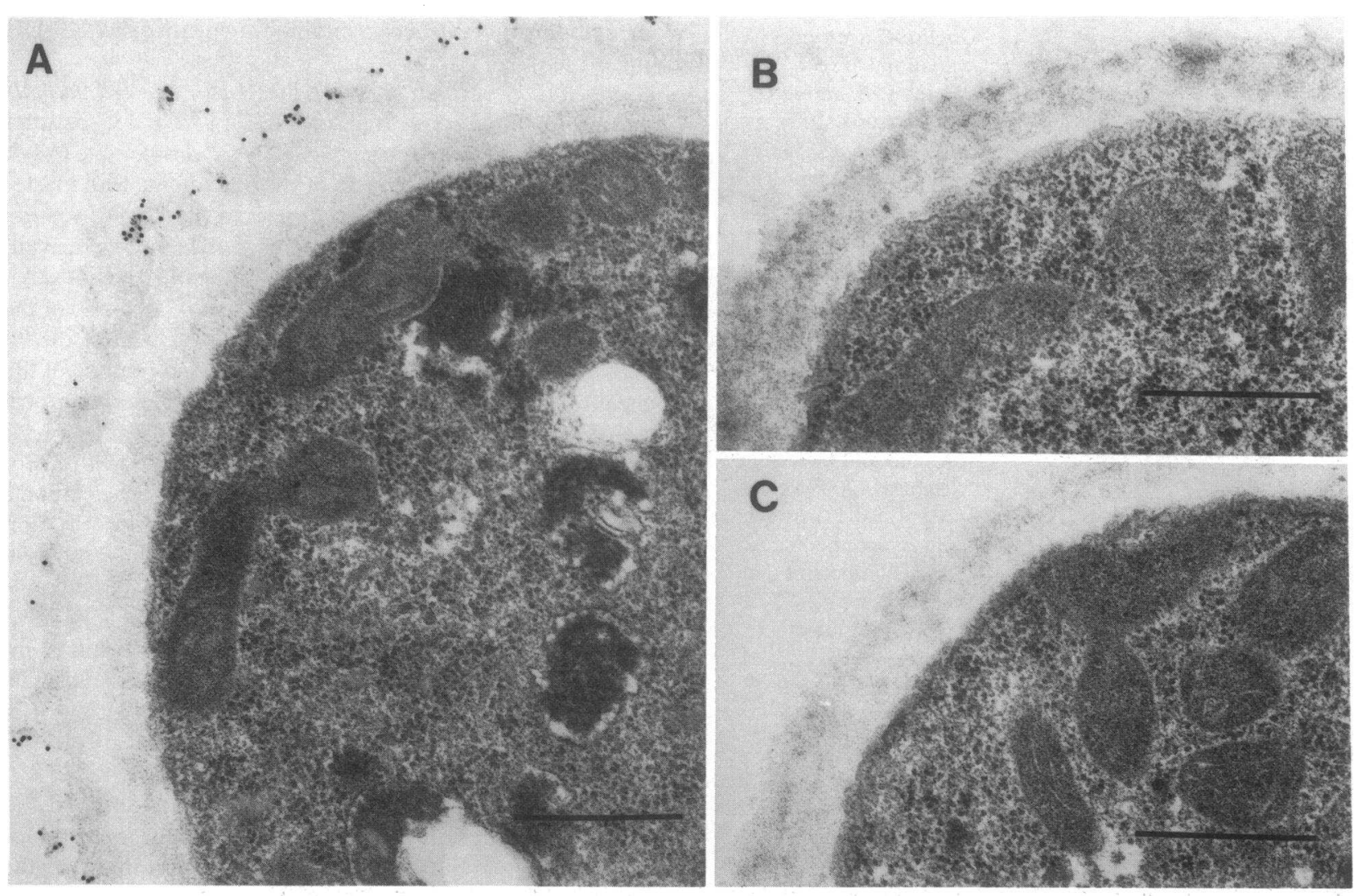

Figure 6. Immunogold staining of Blastomyces dermatitidis yeasts. Serum from a rabbit immunized with WI-1 was used to stain the yeasts $(A)$ and preimmune serum served as a control $(B)$. WI-1 antibody titers are as described in the legend of Fig. 5 . Immune serum adsorbed with $5 \mu \mathrm{g}$ of WI-1 and $B$. dermatitidis yeasts was also studied $(C)$. Results shown are at a serum dilution of 1:100. Protein A gold containing $14 \mathrm{~nm}$ particles was prepared as described in Methods and used at a dilution of 1:15. The bar in the lower right corner of each photo denotes a size of $0.5 \mu \mathrm{m}$.

patients with blastomycosis were available for testing. Each serum specimen had been tested previously in two other studies for antibody to A antigen by enzyme immunoassay $(8,13)$ and was tested in the present study only for antibody to WI-1 by RIA. Of these sera evaluated sequentially by both tests, $82 \%$ were seropositive when tested by RIA in this study, whereas only $58 \%$ had been considered seropositive when tested by enzyme immunoassay previously $(P<0.0001)$ (Fig. 8$)$. The reciprocal GMTs for these assays were $1,871 \pm 1$ and $19 \pm 1$, respectively $(P<0.0001)$.

The pattern of acquisition and clearance of antibody to WI-1 was studied in 35 patients with a known day of onset of illness; 63 sera were tested. Antibody was usually detected by $25 \mathrm{~d}$ after illness onset (GMT, 349 \pm 13 ), titers rose gradually between 26 and $50 \mathrm{~d}$ after onset (GMT, 973 \pm 4 ), peaked between 51 and $75 \mathrm{~d}$ after onset (GMT, 5,324 \pm 3 ), fell gradually between 76 and $150 \mathrm{~d}$ after onset (GMT, 1,941 \pm 10 ), and were often barely detected by $175 \mathrm{~d}$ after onset (GMT, 109 \pm 7 ). The pattern of seroresponse varied with different clinical forms of blastomycosis among the 19 patients with known date of onset of illness or initiation of treatment and serial sera tested (Table II). Patients with acute pulmonary forms of disease, which are usually seen during epidemics, may have detectable antibody at the time of onset but often do not. In contrast, patients with subacute or chronic pulmonary or extrapulmonary forms of disease usually have detectable antibody at the time of presentation, and titers tend to be higher in patients with both pul- monary and extrapulmonary involvement. Patients with isolated cutaneous disease usually had undetectable titers of antibody throughout the duration of illness and treatment.

Determination of the quantity of WI-1 on B. dermatitidis and other yeasts. To generate a standard antigen-inhibition curve, we measured the amount of specific binding of immune rabbit serum to ${ }^{125}$ I-WI-1 blocked by serial dilutions of $500-0.25 \mathrm{ng}$ cold WI-1. Serial dilutions of $10^{8}$ to $10^{2} \mathrm{~B}$. dermatitidis, $H$. capsulatum, and $C$. albicans yeasts were tested in the assay. $125 \mathrm{ng}$ of cold WI-1 completely blocked specific binding; smaller amounts of cold antigen blocked proportionately less binding. Similarly, $10^{6}$ or more $B$. dermatitidis yeasts completely blocked specific binding; $10^{5}$ yeasts blocked $81.2 \%$ of the specific binding and $10^{4}$ yeasts blocked $12.6 \%$. Neither $H$. capsulatum nor $C$. albicans yeasts blocked specific binding. From this assay, we estimate that an individual $B$. dermatitidis yeast harbors $0.93 \mathrm{pg}$ of WI- 1 or $4.7 \times 10^{6}$ WI- 1 molecules on its surface.

\section{Discussion}

In this study, we investigated $B$. dermatitidis yeast cell walls for immunologically relevant molecules using several extraction techniques, SDS-PAGE, and immunoblotting with infected patient sera. We successfully isolated and partially purified and characterized a cell wall antigen, which we have termed WI-1. WI- 1 is abundantly expressed on $B$. dermatitidis yeasts. It was 


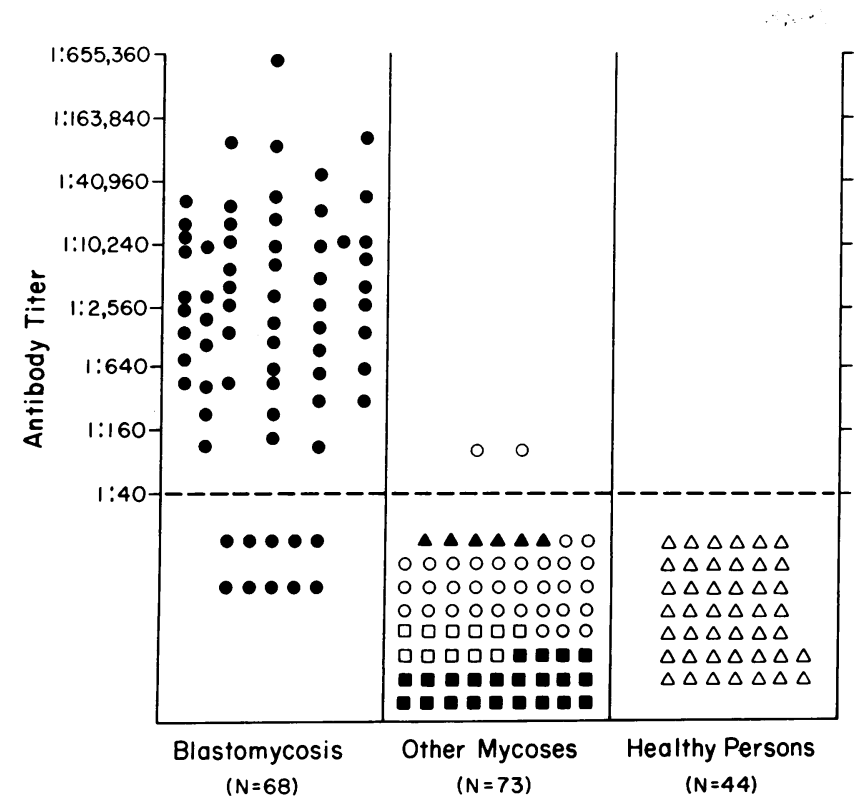

Figure 7. Detection of antibody to WI-1, a $120-k D$ surface protein on $B$. dermatitidis yeasts, in patients with blastomycosis and in control subjects. All 185 sera were tested for antibody to WI-1 using the radioimmunoassay developed in the present study. $\bullet$ Denote patients with blastomycosis; $O$, patients with histoplasmosis; $n$, patients with coccidioidomycosis; $\square$, patients with sporotrichosis; $\Delta$, patients with candidiasis; and $\Delta$, healthy persons. Antibody titers are plotted on a logarithmic scale. The maximum positive titer is shown for patients with multiple sera tested. Values above the broken horizontal line are considered positive.

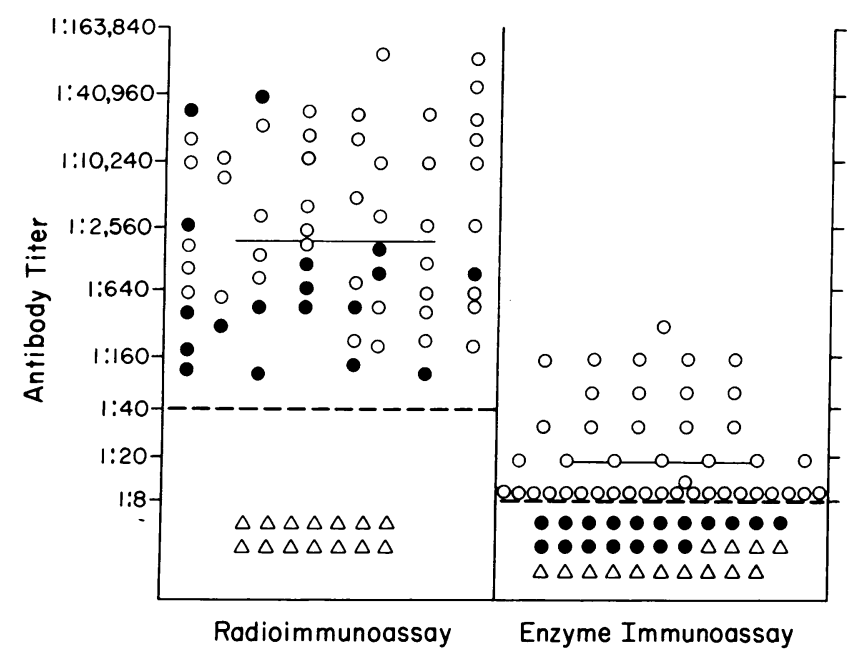

Figure 8. Comparison of RIA and enzyme immunoassay (EIA) for detection of antibody to $B$. dermatitidis in infected patients. Results shown are for 76 sera in 38 patients with blastomycosis. Each serum specimen had been tested previously in two other studies for antibody to A antigen by EIA $(8,13)$ and was tested in the present study only for antibody to WI-1 by RIA. RIA results appear on the left and EIA results, on the right. Antibody titers are plotted on a logarithmic scale. Values above the broken horizontal line are considered positive. These values are 1:40 (RIA) and 1:8 (EIA). $~$ Denote sera that were positive by both RIA and EIA $(n=44)$; $\bullet$, sera that were positive by RIA and negative by EIA $(n=18)$; and $\Delta$, sera that were negative by both RIA and EIA $(n=14)$. No sera were negative by RIA and positive by EIA. The solid horizontal line denotes the geometric mean titer of positive sera in each assay. uniformly found in the five ATCC strains tested (and also in a clinical isolate we tested, data not shown) and it comprised 5\% of the protein in the extract we obtained after freezing and thawing the yeasts. The antigen is a protein and it contains little if any carbohydrate. Although its molecular weight varies slightly between strains, its size is $\sim 120 \mathrm{kD}$. To reproducibly obtain material that will contain WI- 1 as a $120-\mathrm{kD}$ molecule, it appears that rapid dialysis and lyophilization of a freeze extract is the method of choice. Concentrating the freeze extract by using a YM 100 filter before dialysis was associated with recovery of WI-1 of a lower molecular weight in the material obtained. The reason for this was not clear but some degradation of the WI-1 molecule during the filtration procedure is a likely explanation.

WI-1 is a highly immunoreactive molecule and can be used to reliably detect antibody in infected patients. Western blots initially demonstrated that WI-1 was strongly recognized by sera of patients with blastomycosis but not of patients with histoplasmosis or of healthy persons. Furthermore, using a 5 ng target of purified WI-1 labeled with ${ }^{125} \mathrm{I}$, we were able to detect antibody in $85 \%$ of the infected patients and seropositive persons had a GMT of nearly 3,000. 10 patients with blastomycosis had no detectable antibody to WI-1. Possible explanations for these results include: isolated cutaneous disease (three patients); testing several months after treatment was completed (two patients); and testing on presentation with overwhelming pulmonary infection and adult respiratory distress syndrome (two patients). No reason was evident for the negative results in the remaining three patients, who had acute pulmonary disease.

The RIA we describe offers a significant advance for serological studies of blastomycosis. When results of the RIA for detection of antibody to WI-1 are compared to those reported using an enzyme immunoassay for detection of antibody to $\mathrm{A}$ antigen $(8,13)$, several observations can be made: $(a)$ antibody to WI-1 can be detected earlier, occasionally even at the onset of acute pulmonary illness; $(b)$ antibody titers to WI- 1 are far higher, the GMT is $\sim 2.5$ logs greater; and $(c)$ antibody to WI-1 persists for a longer interval, although antibody to both antigens declines to low or undetectable levels by 6 mo after illness onset in patients with resolution or successful treatment of disease (8). We recognize that caution should be used in drawing conclusions about the relative sensitivities of the two tests for detection of antibody in blastomycosis, since the assays were not run in parallel in this study. Despite the high sensitivity of the RIA, specificity was not a significant problem; however, the number of patients with heterologous fungal infections tested was admittedly small. Two patients with serologically confirmed histoplasmosis did have antibody titers to WI-1 just above the positive cutoff value of 1:40. However, increasing the cutoff value to $1: 100$ completely discriminated patients with blastomycosis from those with histoplasmosis without reducing the sensitivity or predictive values of the assay.

WI- 1 appears to be a novel surface protein that is uniquely expressed on $B$. dermatitidis yeasts. SDS-PAGE showed no resemblance between WI-1 and components in the A-antigen or B-ASWS. Approximately $4.7 \times 10^{6}$ WI- 1 molecules are present on a $B$. dermatitidis yeast, whereas no WI-1 could be detected on either $H$. capsulatum or $C$. albicans yeasts. In addition, no significant cross reactivity to WI- 1 was found in patients with histoplasmosis, coccidioidomycosis, sporotri- 


\begin{tabular}{llccc}
\hline & \multicolumn{4}{c}{$\begin{array}{c}\text { Reciprocal of geometric mean antibody titer } \pm 1 \text { SEM by interval from onset of } \\
\text { illness or diagnosis to collection of serum specimen.* }\end{array}$} \\
\cline { 2 - 4 } Clinical feature & $0-25 \mathrm{~d}$ & $26-50 \mathrm{~d}$ & $51-75 \mathrm{~d}$ & $76-150 \mathrm{~d}$ \\
\hline Acute pulmonary disease $(n=29)^{8}$ & $313 \pm 16$ & $2,951 \pm 2$ & $4,307 \pm 3$ & $458 \pm 9$ \\
Chronic pulmonary disease $(n=25)$ & $773 \pm 3$ & $115 \pm 4$ & $62 \pm 6$ & $95 \pm 2$ \\
Chronic pulmonary and extrapulmonary disease $(n=7)$ & 469,770 & $245,241 \pm 1$ & 399 & $880 \pm 610$ \\
Isolated cutaneous disease $(n=6)$ & $<40$ & - & $<40$ & $<40$ \\
\hline
\end{tabular}

Antibody to WI-1, a novel $120 \mathrm{kD}$ surface protein on Blastomyces dermatitidis yeasts, was measured by the radioimmunoassay developed in the present study. * SEM is not recorded if result reflects testing of only one specimen or multiple specimens in which the results were identical. ${ }^{\ddagger}$ Denotes days. ${ }^{\S}$ Denotes number of sera tested in patients with given clinical feature.

chosis, or candidiasis tested by immunoblotting and RIA. It is possible that the two histoplasmosis patients with low antibody titers to WI- 1 recognized portions of the molecule shared with determinants on $H$. capsulatum. Chemotype 1 strains of this organism express a $120-\mathrm{kD}$ cell-wall glycoprotein that reacts with sera from some patients with histoplasmosis and some with blastomycosis (27). However, in contrast to WI-1, serological determinants on that molecule reside in carbohydrate moieties, which account for most (55\%) of the molecule (27). It is surprising that although chemotype 2 strains of $H$. capsulatum and strains of $B$. dermatitidis share a number of structural features of the cell wall $(28,29)$, it is the structurally dissimilar chemotype 1 strain that expresses a $120-\mathrm{kD}$ molecule. Chemotype 1 strains are found principally in Central America and infrequently in North America (30).

An alternative explanation for the low-level cross-reactivity seen in our two patients with histoplasmosis might be the impurities that remained in partially purified WI-1. These were evident in silver stains of some WI-1 eluates. A high molecular weight, heat stable $\left(100^{\circ} \mathrm{C}\right)$ factor known as "Heiner's C" (31), which is a galactomannan common to $B$. dermatitidis, $H$. capsulatum, and Paracoccidiodes brasiliensis (32), has been linked to the cross-reactivity seen in purified preparations of $\mathrm{H}$ and $\mathrm{M}$ components from $H$. capsulatum (33). Finally, we cannot exclude the possibility that the two patients were previously infected with $B$. dermatitidis, since they resided in co-endemic areas and clinical information concerning blastomycosis was not ascertained.

We believe that WI-1 offers important advantages over A antigen for serodiagnosis. A-antigen is a highly complex, impure material that has not been extensively characterized. The potency of A-antigen varies between lots and no reliable method of standardization is available. One study of purified A-antigen demonstrated at least 25 protein and glycoprotein bands by Coomassie blue, periodic acid-Schiff, and silver staining (5). Although that study indicated that the activity of A-antigen was associated with two components, the molecular weights of the components were not described. A-antigen is believed to be a product of the yeast cell wall; however, this also remains uncertain $(3,5)$. In contrast to A-antigen, WI-1 appears to be a nearly homogeneous preparation of a single molecule whose molecular weight and location we have clearly demonstrated. The fact that WI-1 is almost entirely protein should enable the protein content and activity of the antigen from different lots to be standardized. WI- 1 is also easily and rapidly obtained from $\boldsymbol{B}$. dermatitidis yeasts, albeit in small amounts. We have found, however, that freezing and thawing yeasts up to two to three times may significantly enhance the yield of WI-1 (data not shown).

The superficial location of WI-1 on $B$. dermatitidis makes this molecule readily accessible during the host-parasite, cellcell interaction and it is possible that WI-1 is recognized by the cellular immune system in patients with blastomycosis. In a preliminary experiment, the crude extract obtained from freezing and thawing $B$. dermatitidis yeast strain ATCC 60636 elicited lymphocyte blastogenesis in an infected mouse and human, albeit to a lesser extent than did B-ASWS (data not shown), a complex mixture of lipid, polysaccharide and protein with a molecular weight range of 30,000 to 50,000 (34). B-ASWS contains possibly three or four components (6). One fraction confers the high sensitivity and specificity, whereas the others appear to account for cross-reactivity with heterologous fungi, particularly $H$. capsulatum. Because immunologically active components in B-ASWS derive from the most superficial location of the yeast cell wall (alkali extraction is most active at the outer cell wall layer due to cleavage of $\alpha$-1,3-glucan linkages), these components may share determinants on the WI-1 molecule. Features of WI-1 such as its abundant expression and superficial location on yeasts and the purity of isolated preparations suggest that its availability might contribute substantially to studies of the cellular basis for immune recognition, regulation, and control of $B$. dermatitidis and other pathogenic yeasts.

\section{Acknowledgments}

We thank James Stephens and Beth Smith for technical advice and assistance; the medical media and editorial staff, William S. Middleton Memorial Veterans Hospital, for illustration and review of the manuscript, respectively; the Anatomy department, University of Wisconsin-Madison, and the Pathology department, William S. Middleton Memorial Veterans Hospital, for assistance with electron microscopy; Bradford Schwartz for review of the manuscript; and the Secretarial Center of the Department of Medicine, University of Wisconsin Hospital and Clinics for preparation of the manuscript.

This work was supported in part by the Veterans Administration Medical Research Service, by National Institutes of Health grants AI-15682 and AI-00905, and by a Gilbert A. Dalldorf Fellowship in Medical Mycology awarded to Dr. Klein by the Infectious Disease Society of America.

\section{References}

1. Denton, J. F., E. S. McDonough, L. Ajello, and R. J. Ausherman. 1961. Isolation of Blastomyces dermatitidis from soil. Science (Wash. DC). 133:1126-1127. 
2. Sarosi, G. A., K. J. Hammerman, F. E. Tosh, and R. S. Kroneberg. 1974. Clinical features of acute pulmonary blastomycosis. $N$. Engl. J. Med. 290:540-543.

3. Green, J. H., W. K. Harrell, J. E. Johnson, and R. Benson. 1980. Isolation of an antigen from Blastomyces dermatitidis that is specific for the diagnosis of blastomycosis. Curr. Microbiol. 4:293-296.

4. Cox, R. A., and H. W. Larsh. 1974. Isolation of skin test-active preparations from yeast-phase cells of Blastomyces dermatitidis. Infect. Immun. 10:42-47.

5. Young, K. D., and H. W. Larsh. 1981. Identification of the active precipitin components in a purified preparation of the A antigen of Blastomyces dermatitidis. Infect. Immun. 33:171-177.

6. Lancaster, M. V., and R. F. Sprouse. 1976. Isolation of a purified skin test antigen from Blastomyces dermatitidis yeast-phase cell wall. Infect. Immun. 14:623-625.

7. Klein, B. S., J. N. Kuritsky, W. A. Chappell, et al. 1986. Comparison of the enzyme immunoassay, immunodiffusion, and complement fixation tests in detecting antibody in human sera to the $A$ antigen of Blastomyces dermatitidis. Am. Rev. Respir. Dis. 133:144-148.

8. Klein, B. S., J. M. Vergeront, L. Kaufman, R. W. Bradsher, U. N. Kumar, G. Mathai, B. Varkey, and J. P. Davis. 1987. Serologic tests for blastomycosis: analysis of experience during a large pointsource outbreak in Wisconsin. J. Infect. Dis. 155:262-268.

9. Turner, S., L. Kaufman, and M. Jalbert. 1986. Diagnostic assessment of an enzyme-linked immunosorbent assay for human and canine blastomycosis. J. Clin. Microbiol. 23:294-297.

10. Kanetsuna, F., L. M. Carbonell, R. E. Moreno, and J. Rodriguez. 1969. Cell wall composition of the yeast and mycelial forms of Paracoccidioides brasiliensis. J. Bacteriol. 97:1036-1041.

11. Kanestsuna, F., and L. M. Carbonell. 1971. Cell wall composition of the yeastlike and mycelial forms of Blastomyces dermatitidis. $J$. Bacteriol. 106:946-948.

12. Klein, B. S., J. M. Vergeront, R. J. Weeks, U. N. Kumar, G. Mathai, B. Varkey, L. Kaufman, R. W. Bradsher, J. F. Stoebig, J. P. Davis, et al. 1986. Isolation of Blastomyces dermatitidis in soil associated with a large outbreak of blastomycosis in Wisconsin. $N$. Engl. J. Med. 314:529-534.

13. Klein, B. S., J. M. Vergeront, A. F. DiSalvo, L. Kaufman, and J. P. Davis. 1987. Two outbreaks of blastomycosis in Wisconsin: Isolation of Blastomyces dermatitidis from riverbank soil and evidence of its transmission along waterways. Am. Rev. Respir. Dis. 136:13331338.

14. Lee, K. L., H. R. Buckley, and C. C. Campbell. 1975. An amino acid liquid synthetic medium for the development of mycelial and yeast forms of Candida albicans. Sabouraudia. 13:148-153.

15. Yokogawa, K., S. Kawata, S. Nishimura, Y. Ikeda, and Y. Yoshimura. 1974. Mutanolysin, bacteriolytic agent for cariogenic streptococci: partial purification and properties. Antimicrob. Agents Chemother. 6:156-165.

16. Yokogawa, K., S. Kawata, T. Takemura, and Y. Yoshimura. 1975. Purification and properties of lytic enzymes from Streptomyces globisporus 1829. Agric. Biol. Chem. 39:1533-1543.

17. Wrobleski, F., and J. S. LaDue. 1955. Lactic dehydrogenase activity in blood. Proc. Soc. Exp. Biol. Med. 90:210-213.
18. Laemmli, U. K. 1970. Cleavage of structural proteins during the assembly of the head of bacteriophage T4. Nature (Lond.). 227:680-685.

19. Heukeshoven, J., and R. Dernick. 1985. Simplified method for silver staining of proteins in polyacrylamide gels and the mechanism of silver staining. Electrophoresis. 6:103-112.

20. Kapitany, R. A., and E. J. Zebrowksy. 1973. A high resolution PAS stain for polyacrylamide gel electrophoresis. Anal. Biochem. 56:361-369.

21. Towbin, H., T. Staehelin, and J. Gordon. 1979. Electrophoretic transfer of proteins from polyacrylamide gels to nitrocellulose sheets: procedure and some applications. Proc. Natl. Acad. Sci. USA. 76:4350-4354.

22. Jones, J. M. 1980. Quantitation of antibody against cell wall mannan and a major cytoplasmic antigen of Candida in rabbits, mice, and humans. Infect. Immun. 30:78-89.

23. Minden, P., and R. S. Farr. 1967. The ammonium sulfate method to measure antigen-binding capacity. In Handbook of Experimental Immunology. D. M. Weir, editor. F. A. Davis Co., Philadelphia. 463-492.

24. Greenfield, R. A., J. L. Stephens, M. J. Bussey, and J. M. Jones. 1983. J. Lab. Clin. Med. 101:758-770.

25. Lucocq, J. M., and J. Roth. 1985. Colloidal gold and colloidal silver-metallic markers for light microscopic histochemistry. In Techniques in Immunocytochemistry. Vol. 3. G. R. Bullock, and R. Petrusz, editors. Academic Press Inc., London. 203-236.

26. Fleiss, J. L. 1981. Statistical Methods for Rates and Proportions. 2nd ed. John Wiley and Sons, New York. 117-119.

27. Reiss, E., S. E. Miller, W. Kaplan, and L. Kaufman. 1977. Antigenic, chemical, and structural properties of cell walls of Histoplasma capsulatum yeast-form chemotypes 1 and 2 after serial enzymatic hydrolysis. Infect. Immun. 16:690-700.

28. Domer, J. 1971. Monosacchardie and chitin content of cell walls of Histoplasma capsulatum and Blastomyces dermatitidis. J. Bacteriol. 107:870-877.

29. Kanetsuna, F., L. M. Carbonell, F. Gil, and I. Azuma. 1974. Chemical and ultrastructural studies on the cell walls of the yeastlike and mycelial forms of Histoplasma capsulatum. Mycopathol. Mycol. Appl. 54:1-13.

30. Kaufman, L., and S. Blumer. 1966. Occurrence of serotypes among Histoplasma capsulatum strains. J. Bacteriol. 91:1434-1439.

31. Heiner, D. C. 1958. Diagnosis of histoplasmosis using precipitin reactions in agar gel. Pediatrics 22:616-629.

32. Azuma, I., F. Kanetsuna, Y. Tanaka, Y. Yamamura, and L. M. Carbonell. 1974. Chemical and immunological properties of galactomannans obtained from Histoplasma duboisii, Histoplasma capsulatum, Paracoccidioides brasiliensis, and Blastomyces dermatitidis. Mycopathol. Mycol. Appl. 54:111-125.

33. Reiss, E. 1986. Molecular Immunology of Mycotic and Actinomycotic Infections. Elsevier/North Holland Publishing Co., New York. 77-102.

34. Cox, R. A., and H. W. Larsh. 1974. Yeast- and mycelial-phase antigens of Blastomyces dermatitidis: Comparison using disc gel electrophoresis. Infect. Immun. 10:48-53. 